\title{
COVID-19 and the Working Class: \\ Harm, Resistance, and Solidarity in the United States
}

\author{
Elizabeth B. Pathak, $\mathrm{PhD}^{1}$ \\ Janelle Menard, $\mathrm{PhD}^{1}$ \\ Rebecca B. Garcia, MSN ${ }^{1,2}$
}

${ }^{1}$ Women's Institute for Independent Social Enquiry (WiiSE), Olney, MD

${ }^{2}$ Premise Health, Brentwood, TN

\section{Address correspondence to:}

Dr. Elizabeth Pathak, President

Women's Institute for Independent Social Enquiry, Olney MD.

Phone: 813-610-8715. Email: beth.pathak@wiise-usa.org

\section{Competing Interest Statement: None.}

Word Count: 2,436

\begin{abstract}
Compared to many other wealthy nations, the United States lacks a strong social safety net, has weak legal protections for workers, has suffered long-term declines in unionization, and has eroded the gains in prosperity achieved by the working class in the post-WWII era. Consequently, despite advancements in science and medicine, the U.S. working class has suffered great harms during the COVID-19 pandemic, from the direct effects of illness and mortality and from indirect familial, social, and economic impacts. The failure of the federal government to protect blue collar, service, and retail sales workers with strong mandatory worksite infection control regulations has further endangered working class communities. The dearth of federal leadership has been countered by solidarity and a diversified set of pandemic monitoring and mitigation efforts on the part of worker organizations (primarily labor unions), social service NGOs, Indigenous nations, and communities of color. Defeating the COVID-19 syndemic will require continued working class solidarity, an ethical framework for envisioning a future which prioritizes social and racial justice, and structural economic and sociopolitical transformations.
\end{abstract}




\section{Population, Political Economy, and the Roots of the COVID-19 Pandemic}

For thousands of years, human infectious diseases have disproportionately afflicted the poor. ${ }^{1-3}$ Early regional shifts in subsistence strategies from foraging to agriculture led to explosive human population growth. ${ }^{4}$ The subsequent development of larger, more complex societies required labor specialization and environmental adaptation for food production and animal husbandry. The detrimental health effects of these subsistence and demographic transitions included malnutrition, reduced body stature, and increases in infectious disease, dental caries, and sedentism. ${ }^{4-6}$ These conditions set the stage for subsequent patterns of human disease. Although the Industrial Revolution brought technological innovations, increased material wealth for emerging middle classes, and advancements in science and medicine, the benefits of modernization were not enjoyed equally. ${ }^{7}$

A key tenet of classic epidemiologic transition theory ${ }^{8}$ posits that improvements in population health in modern times are dependent on a shift from a predominance of infectious to non-infectious diseases through linear stages of socioeconomic progress. However, the political, economic, and ecosocial realities of the past 50 years have belied this tidy narrative, ${ }^{9}$ as evidenced by the reemergence of infectious disease pandemics ${ }^{10-12}$ and syndemics. ${ }^{13-15}$ Despite the great wealth of the former colonial powers, declines in regular employment ${ }^{16}$ coupled with increasing precarity of blue collar and service work, ${ }^{17,18}$ the housing crisis, $^{19,20}$ aging urban infrastructure, ${ }^{21}$ influx of refugees, ${ }^{22}$ exploitation of immigrants to meet workforce demands, ${ }^{23,24}$ and climate crisis-abetted agricultural and environmental destabilization ${ }^{25}$ have all contributed to widening economic inequalities ${ }^{26}$ and increases in class conflict. ${ }^{27}$ The resulting degradations of local social environments ${ }^{28}$ create the material conditions for zoonotic spillovers and proliferation of novel pathogens. ${ }^{10,25,29,30}$ The United States, despite its advancements in science and medicine, is particularly vulnerable compared with most other wealthy nations, ${ }^{31}$ because of its absence of a strong social safety net, ${ }^{32}$ weak legal protections for 
workers, ${ }^{33}$ long-term declines in unionization, ${ }^{27}$ erosion of the gains in prosperity achieved by the working class in the post-WWII era, ${ }^{26}$ and for-profit healthcare system. ${ }^{34,35}$

\section{The COVID-19 Syndemic: Airborne SARS-CoV-2 / Hazardous Labor / Structural Racism}

"It's a vicious cycle. You're not living, you're surviving. Domestic work is not when you choose to do it, but when they need your services. We're completely invisible. We're visible when it comes to ensuring everything is clean, but we're invisible when it comes to our rights."

"Before the pandemic, I was living with my sister and her husband. In the apartment [there were 15 people]. The pantry in an apartment in one of those 'nice' zip codes - where they probably have no idea that COVID-19 exists - that's a [separate] living space for us, the newly arrived. [During the pandemic], I found a closet within someone else's home for me and my two children. It was 72 by 32 inches and rent was \$1,100 a month, with bills included."

Cindia Martinez, 34, housekeeper in San Francisco, quote excerpted from: ${ }^{36}$

The COVID-19 pandemic has been shaped by complex interactions of ecological, biological, demographic, social, economic, and political factors. Understanding the complexity of these interactions requires a theoretical framework that integrates biosocial processes with the forces that generate inequalities in exposure risk, infections, illness severity, and mortality. Numerous studies have illustrated the central role of social contexts over individual biologies in the production of health disparities. ${ }^{37-39} \mathrm{~A}$ social environmental frame ${ }^{40}$ to the problem of SARS-CoV-2 transmission must consider the multiple spatial scales at which airborne infection risk is structured and reinforced by social class and racial/ethnic inequalities. ${ }^{41,42}$ These nested and overlapping spatial scales include the individual body, the household, the school, the worksite, the neighborhood, the city, the region, the state, the nation, and the globe.

The syndemic theoretical framework ${ }^{13,43,44}$ has been proposed to make sense of the COVID-19 pandemic in specific global contexts. ${ }^{14,15,45-47}$ Syndemics are defined as public health threats which arise 
from the interaction and synergy of two or more separate disease processes or risk conditions that are exacerbated by social environmental factors. ${ }^{44}$ The recognition of synergistic relationships between biological, social, economic, and political factors that influence disease patterns more clearly elucidates complex biosocial pathways than conventional biomedical or individual behavioral causal models.

A recent report on the joint impacts of social class, race/ethnicity, and gender on COVID-19 mortality, ${ }^{48}$ found that among working age adults, COVID-19 mortality in 2020 was five times higher among the working class (those with no college education) than among college graduates. Within each social class, male gender and non-white race/ethnicity resulted in much higher COVID-19 death rates. Working class jobs (blue collar, service, and retail sales) are "never remote" occupations that require onsite labor, and offer workers little control over their time or environment. The American Time Use Survey of 6,600 adults found that working at a workplace (not home) during May - December 2020 was most frequent for transportation workers (91\%), service workers (88\%), workers with no high school diploma (89\%), and high school graduates with no college (87\%). ${ }^{49}$ A major U.K. study on socioeconomic inequalities and COVID- $19^{50}$ found that percent working from home during the study period and the "proximity to others" rating of individual occupations were both associated with COVID19 mortality. ${ }^{51}$

The study of social class disparities in COVID-19 mortality, ${ }^{48}$ the UK report, ${ }^{50}$ important theoretical development, ${ }^{42}$ worksite COVID-19 outbreak investigations ${ }^{52-58}$ and other empirical studies, ${ }^{17,59-63}$ reveal a tripartite syndemic - comprised of airborne SARS-CoV-2, hazardous labor, and structural racism - as a primary driver of the COVID-19 pandemic. Ecological correlation studies of county-level socioeconomic indicators and crude (non-age-adjusted) death rates have found higher COVID-19 mortality in counties with higher economic adversity, ${ }^{64-72}$ poorer housing quality ${ }_{1}^{65,73}$ greater household crowding ${ }^{64,74}$ higher levels of air pollution, ${ }^{75,76}$ higher social vulnerability as measured by the 
CDC index, ${ }^{46,77-80}$ higher percent Black and/or other racial minority population, ${ }^{64,65,67,70-72,75,76,79,81-84}$ and greater neighborhood racial segregation. ${ }^{69,70,76,85,86}$ Two ecological studies which analyzed age-adjusted COVID-19 mortality in small areas found similar results to the county studies..$^{87,88}$

Importantly, a syndemic paradigm also readily discredits racist bioessentialist claims that masquerade as empirical explanations for disease disparities. Operational assumptions of homogeneity within racial/ethnic groups can reinforce a bioessentialist paradigm ${ }^{89-91}$ that situates and explains observed racial/ethnic disparities in health outcomes as an inevitable consequence of the frailties of human bodily constitutions, ${ }^{92}$ rather than as the embodiment of outcomes of adversarial social relations such as racism, class exploitation, and gender violence. ${ }^{44,93-95}$ In the context of the COVID-19 pandemic, the hegemonic biomedical focus on bodily frailty (variously attributed to "genetic susceptibility," "unhealthy lifestyles," or "cultural behavior patterns") moralizes otherness and has readily translated into decontextualized pervasive rhetoric in public discourse on "pre-existing conditions," "comorbidities," and "vaccine hesitancy" as key explanations for racial/ethnic disparities in COVID-19 incidence and outcomes. ${ }^{96}$

Social class mortality disparities are just the tip of the syndemic inequality iceberg. For every working age adult COVID-19 decedent, there are dozens to hundreds of survivors. The socioeconomic and familial consequences of COVID-19 diagnosis and illness can be devastating even for those who fully recover their health. Loss of income, job loss, large medical and hospital bills not covered by insurance, and social stigmatization are just a few of the consequences which impact the working class disproportionately. Moreover, the long term health sequelae of SARS-CoV-2 infection are severe in some survivors, leading to crippling fatigue, work-related disability, and inability to perform caretaking tasks for children, elders, and dependent adults. ${ }^{97,98}$ All of these negative consequences can lead to familial and household instability, in some cases culminating in increases in household crowding, 
evictions from rental housing, and homelessness. Even among working class adults who have never tested positive for COVID-19, the pandemic has been shown to cause job lay-offs, ${ }^{47}$ food insecurity, ${ }^{47}$ sleep disturbances ${ }^{99}$ and psychosocial stress. ${ }^{99}$

\section{Working Class and Minority Community Mobilizations Against COVID-19}

"I'd really like for people to value the work of those who take care of elderly people and children, because they can't fend for themselves. And it's not valued."

Leticia López, 30, housekeeper in Houston, quote excerpted from: ${ }^{36}$

"In the pandemic, employers asked us to use toxic products that were more harmful to our health and worsened my condition. [...] As housekeepers, we don't have health or safety protections. How is it possible that our work, which makes other work possible, is something that isn't properly valued? We're human beings and we deserve protections."

Evelin Alfaro, 40, housekeeper in San Francisco, quote excerpted from: ${ }^{36}$

The Occupational Health and Safety Act of 1971 requires employers to provide "a place of employment which [is] free from recognized hazards that are causing or are likely to cause death or serious physical harm. ${ }^{1100}$ The U.S. Occupational Health and Safety Administration (OSHA) is a regulatory and enforcement agency which has the power to issue mandatory safety standards, inspect worksites, issue citations, and levy monetary fines against employers found in violation of safe workplace standards. ${ }^{101}$ Unfortunately, years of extremely insufficient funding by congress and erosion of authority by anti-labor presidential administrations have crippled OSHA's ability to protect American workers. ${ }^{101,102}$ During 2020-2021, OSHA has received thousands of worker complaints about COVID-19 and unsafe working conditions, but has investigated only a small fraction of those complaints. As of May 2021, only 346 employers had been cited for violations and the average fine was less than $\$ 4,000 .^{102}$ 
After promises from the new presidential administration in January 2020, labor unions and the public health community had expected OSHA to issue an Emergency Temporary Standard (ETS), covering all worksites in the U.S., with enhanced and enforceable requirements for workplace safety from airborne infectious disease. ${ }^{101}$ This ETS was expected to conform to the NIOSH hierarchy of controls (Figure 1), and place the burden of ensuring workplace safety on employers and not on worker behaviors. ${ }^{103}$ Instead, the administration was overly optimistic in the face of declining daily COVID-19 case counts in the spring of 2021 in the U.S., and downplayed the Delta variant surge in Asia. In June 2021, OSHA issued an ETS which only covered healthcare workplaces such as hospitals and nursing homes, ${ }^{104}$ leaving the vast majority of workplaces covered only by voluntary safety guidelines.

Figure 1.

National Institute of Occupational Safety and Health (NIOSH) Diagram of Hierarchy of Controls of Occupational Hazards to Workers.

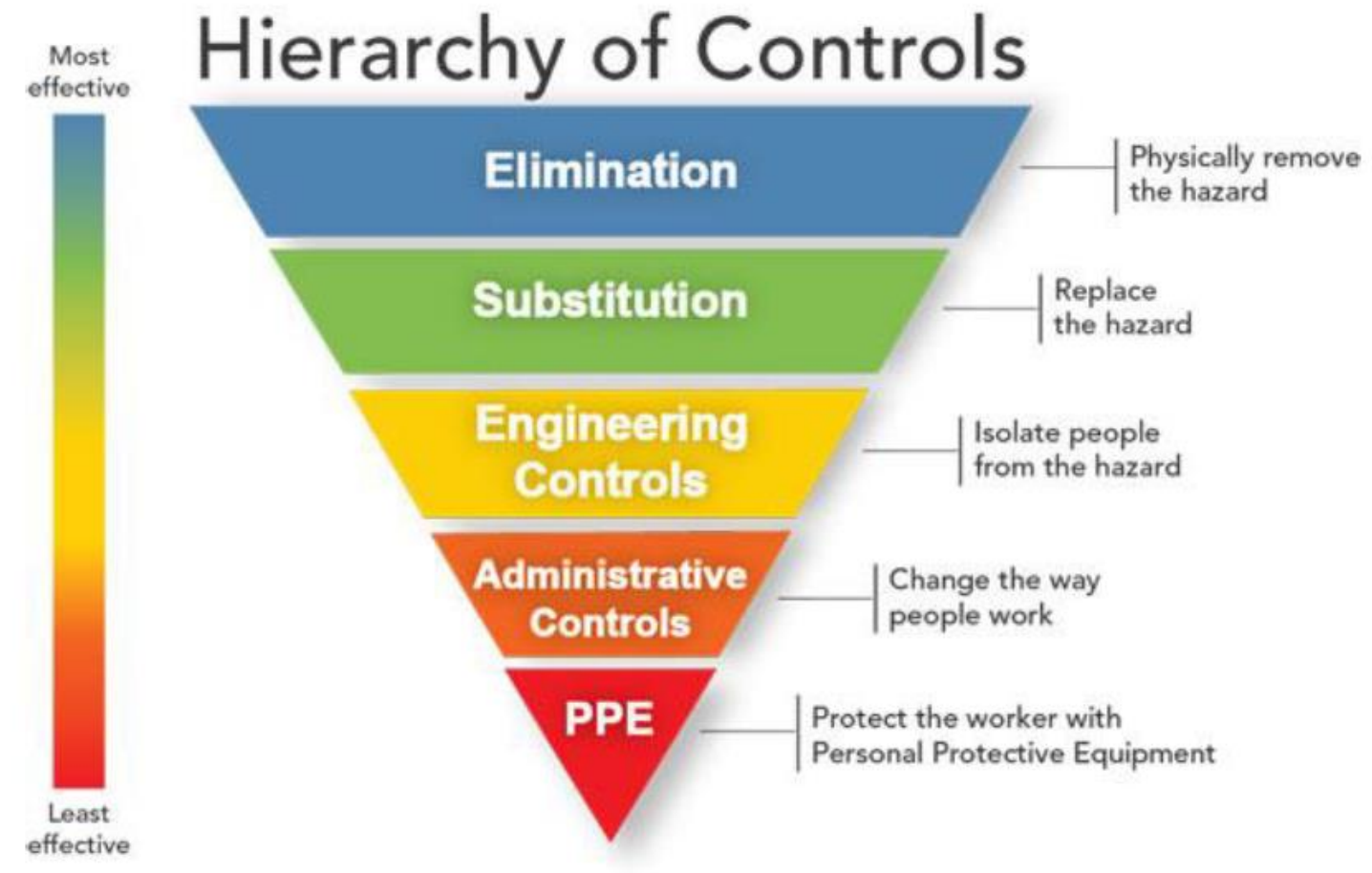

Source: https://www.cdc.gov/niosh/topics/hierarchy/default.html 
The dearth of federal agency leadership and initiative to protect U.S. workers from COVID-19 has been met by solidarity and a diversified set of pandemic monitoring and mitigation efforts on the part of worker organizations (primarily labor unions), social service NGOs, and communities of color. There is no national surveillance system for tracking COVID-19 testing, cases, hospitalizations, or deaths by occupation, industry, or any other measure of social class. ${ }^{102,105}$ Only a few state health departments require reporting of worksite outbreaks by employers. The only federal agency to require reporting of worksite COVID-19 infections is the Center for Medicare and Medicaid Services, for nursing home workers only. As of September 26, 2021, over 650,000 cases and over 2,000 deaths among nursing home staff had been reported. ${ }^{106}$

Several worker-led grassroots efforts have attempted to compensate for the lack of federal government leadership in tracking worksite transmissions of SARS-CoV-2. The Food and Environment Reporting Network tracked COVID-19 outbreaks in the food processing industry for 500 days, gathering data from local and state health agencies, unions, local news reporting, and employers. ${ }^{107,108}$ On the last day of their unfunded volunteer surveillance project (September 2, 2021) a cumulative total of 91,717 workers at 1,466 meatpacking and food processing plants had been reported as confirmed cases of COVID-19. ${ }^{107}$ Similarly, several national labor unions implemented their own COVID-19 tracking systems, including surveys of workers about worksite conditions and employer compliance with current mitigation recommendations from the $\mathrm{CDC}$ and OSHA. ${ }^{102}$

Labor unions have provided important protections to workers impacted by COVID-19, through political and legislative advocacy ${ }^{102,109}$ and contract negotiations for specific infection prevention and control concessions. ${ }^{110}$ Furthermore, unionized worksites experienced greater compliance with public health recommended mitigation strategies ${ }^{111}$ and lower COVID-19 mortality rates ${ }^{112}$ compared with similar non-unionized worksites. 
In a recent study of social class and COVID-19 mortality, it was shown that among the working class and those with some college, Indigenous men and women suffered the highest rates of COVID-19 mortality compared with all other racial/ethnic groups. ${ }^{48}$ Indigenous people have proactively advocated for their most vulnerable community members. In Minnesota, tribal leaders meet regularly with the Lieutenant Governor and officials of the Department of Health to share concerns and provide advice on mitigation strategies. ${ }^{113}$ On the Navajo Nation, over 100 Diné community health representatives (CHRs) have taken on extensive new responsibilities to serve rural tribal members during the pandemic. In addition their pre-pandemic duties as lay health educators, the CHRs conduct crisis management, logistics planning, food and water distributions, contact tracing, social work referrals, and mental health counseling. ${ }^{114}$

Native Hawaiians and Pacific Islanders, who prior to the COVID-19 pandemic suffered high rates of low-wage employment, poverty, homelessness, and incarceration, have responded to the pandemic's devastating impacts with grassroots community solidarity initiatives. In Hawaii and the western U.S., local groups have organized elder care services, and cultural and social events to combat the stress and isolation of the pandemic. ${ }^{115}$

The Navajo Nation CHR program, with its emphasis on self-determination and care that is both community-directed and community-centered, is a model for workers and local communities across the U.S. ${ }^{114}$ Similarly, in California and other states, new local coalitions of Hispanic farmworkers, public health workers, community medical clinic staff, and some growers and employers have formed to provide services, education, viral testing, quarantine and isolation housing, and vaccinations to migrant farmworkers and their families. ${ }^{116}$ 


\section{CONCLUSION}

"For six years, I nannied two children seven days a week. [...] The children's parents are doctors. [...] They didn't raise my salary in six years. I didn't mind all that work because I loved the children so much. In December 2020 I didn't go to work because my husband tested positive for COVID-19. [...] They told me to stay home and take care of myself. When I recovered, I sent them a negative test, and they fired me. Just like that, without saying anything. They didn't let me say goodbye to the kids. That hurts a lot."

Leticia López, 30, housekeeper in Houston, quote excerpted ${ }^{36}$

"By dissolving social class divisions into occupational categories, educational attainment, and income, the socioeconomic status concept glosses over the structural nature of one class exploiting others. ... [It could] lead one to [falsely] conclude that racial and ethnic inequities in health can be eliminated without structural changes in economic relations."

Oliver and Muntaner ${ }^{117}$

The human history, thousands of years long, of social stratification and consequent extreme disparities in the burden of infectious diseases is daunting but does not preclude the possibility for transformational social change. A moral reckoning, ${ }^{118}$ an ethos of care, ${ }^{41}$ and a moral fusion coalition, ${ }^{119}$ have been advanced as ethical frameworks for envisioning and advocating for a future in which social and racial justice and public health for all are valued above unlimited economic growth and concentration of wealth and power in the hands of a few. Defeating the COVID-19 syndemic will require working class solidarity and structural economic and sociopolitical transformations. 


\section{REFERENCES}

1. Shah S. Fever: How malaria has ruled humankind for 500,000 years. New York: Sarah Crichton Books; 2010.

2. Adams LV, Butterly JR. Diseases of Poverty: Epidemiology, Infectious Diseases, and Modern Plagues. Hanover, New Hampshire: Dartmouth College Press; 2015.

3. Watts S. Epidemics and History: Disease, Power and Imperialism. New Haven: Yale University Press; 1997.

4. Armelagos $\mathrm{GJ}$, Goodman $\mathrm{AH}$, Jacobs $\mathrm{KH}$. The origins of agriculture: Population growth during a period of declining health. Population and Environment. 1991;13(1):9-22 https://doi.org/10.1007/BF01256568.

5. Armelagos GJ, Brown PJ, Turner B. Evolutionary, historical and political economic perspectives on health and disease. Soc Sci Med. 2005;61(4):755-765

6. Cohen MN. Health and the Rise of Civilization. New Haven, CT: Yale University Press; 1991.

7. Engels F. The Condition of the Working Class in England. Leipzig Germany: Otto Wigand; 1845.

8. Omran AR. The epidemiologic transition. A theory of the epidemiology of population change. Milbank Mem Fund Q. 1971;49(4):509-538

9. McKeown RE. The Epidemiologic Transition: Changing Patterns of Mortality and Population Dynamics. Am J Lifestyle Med. 2009;3(1 Suppl):19s-26s

10. Garrett L. The Coming Plague: Newly Emerging Diseases in a World Out of Balance. New York: Farrar, Straus, and Giroux; 1994.

11. Cherry JD, Krogstad P. SARS: the first pandemic of the 21st century. Pediatr Res. 2004;56(1):1-5

12. Webby RJ, Webster RG. Are we ready for pandemic influenza? Science. 2003;302(5650):15191522

13. Singer $\mathrm{M}$, Clair S. Syndemics and public health: reconceptualizing disease in bio-social context. Med Anthropol Q. 2003;17(4):423-441

14. Fronteira I, Sidat M, Magalhães JP, et al. The SARS-CoV-2 pandemic: A syndemic perspective. One Health. 2021;12:100228

15. Yadav UN, Rayamajhee B, Mistry SK, Parsekar SS, Mishra SK. A Syndemic Perspective on the Management of Non-communicable Diseases Amid the COVID-19 Pandemic in Low- and Middle-Income Countries. Front Public Health. 2020;8:508

16. Muntaner C. Digital Platforms, Gig Economy, Precarious Employment, and the Invisible Hand of Social Class. Int J Health Serv. 2018;48(4):597-600

17. Matilla-Santander N, Ahonen E, Albin M, et al. COVID-19 and Precarious Employment: Consequences of the Evolving Crisis. Int J Health Serv. 2021;51(2):226-228

18. Landsbergis PA, Grzywacz JG, LaMontagne AD. Work organization, job insecurity, and occupational health disparities. Am J Ind Med. 2014;57(5):495-515

19. Desmond M. Evicted: Poverty and Profit in the American City. New York: Crown Publishing Group; 2017.

20. Moskowitz P. How to Kill a City: Gentrification, Inequality, and the Fight for the Neighborhood New York: Nation Books; 2017.

21. Petroski H. The Road Taken: The History and Future of America's Infrastructure. New York: Bloomsbury; 2016.

22. Kingsley P. The New Odyssey: The Story of the Twenty-First Century Refugee Crisis. New York: Liveright Publishing Corporation; 2017. 
23. Loza M. Defiant Braceros: How Migrant Workers Fought for Racial, Sexual, and Political Freedom. Chapel Hill: University of North Carolina Press; 2016.

24. Milkman R. Immigrant Labor and the New Precariat. Cambridge: Polity Press; 2020.

25. Wallace $R$, Wallace RG. Blowback: new formal perspectives on agriculturally driven pathogen evolution and spread. Epidemiol Infect. 2015;143(10):2068-2080

https://www.ncbi.nlm.nih.gov/pubmed/26050716.

26. Piketty T. Capital in the Twenty-First Century. Cambridge, Massachusetts: Harvard University Press; 2014.

27. Greenhouse S. Beaten Down, Worked Up: The Past, Present, and Future of American Labor. New York: Anchor; 2020.

28. Barnett E, Casper M. A Definition of Social Environment. American Journal of Public Health. 2001;91(3):1

29. Wallace R, Wallace D, Wallace R. Farming Human Pathogens: Ecological Resilience and Evolutionary Process. Dordrecht: Springer; 2009.

30. Dobson AP, Pimm SL, Hannah L, et al. Ecology and economics for pandemic prevention. Science. 2020;369(6502):379-381 https://www.science.org/doi/10.1126/science.abc3189?url_ver=Z39.882003\&rfr_id=ori\%3Arid\%3Acrossref.org\&rfr_dat=cr_pub++0pubmed\&.

31. Perry BL, Aronson B, Pescosolido BA. Pandemic precarity: COVID-19 is exposing and exacerbating inequalities in the American heartland. Proc Natl Acad Sci U S A. 2021;118(8)

32. Burt MR, Smith Nightingale D. Repairing the U.S. Social Safety Net. Washington D.C.: Urban Institute Press; 2010.

33. Heymann J, Sprague A, Earle A, McCormack M, Waisath W, Raub A. US Sick Leave In Global Context: US Eligibility Rules Widen Inequalities Despite Readily Available Solutions. Health Aff (Millwood). 2021;40(9):1501-1509

34. Whiteis DG. Third world medicine in first world cities: capital accumulation, uneven development and public health. Soc Sci Med. 1998;47(6):795-808

35. Whiteis DG. Poverty, policy, and pathogenesis: Economic justice and public health in the US. Critical Public Health. 2000;10(2):257-271 https://doi.org/10.1080/09581590050075989.

36. Martinez M. In Their Own Words: 5 Latina Immigrant Housekeepers on How the Pandemic has Impacted Their Lives. www.thelily.com. October 6, 2021, 2021 https://www.thelily.com/in-theirown-words-5-latina-immigrant-housekeepers-on-how-the-pandemic-has-impacted-theirlives/?tid=more_from_lily.

37. Farmer P. Infections and Inequalities: The Modern Plagues. 1 ed: University of California Press; 1999.

38. Holmes SM, Hansen $\mathrm{H}$, Jenks $\mathrm{A}$, et al. Misdiagnosis, Mistreatment, and Harm - When Medical Care Ignores Social Forces. New England Journal of Medicine. 2020;382(12):1083-1086 https://www.nejm.org/doi/full/10.1056/NEJMp1916269.

39. Gravlee CC, Non AL, Mulligan CJ. Genetic Ancestry, Social Classification, and Racial Inequalities in Blood Pressure in Southeastern Puerto Rico. PLOS ONE. 2009;4(9):e6821 https://doi.org/10.1371/journal.pone.0006821

https://www.ncbi.nlm.nih.gov/pmc/articles/PMC2731885/pdf/pone.0006821.pdf.

40. Barnett $\mathrm{E}$, Casper M. A definition of "social environment". Am J Public Health. 2001;91(3):465

41. Lopez PJ, Neely AH. Fundamentally uncaring: The differential multi-scalar impacts of COVID-19 in the U.S. Soc Sci Med. 2021;272:113707 
42. McClure ES, Vasudevan P, Bailey Z, Patel S, Robinson WR. Racial Capitalism Within Public HealthHow Occupational Settings Drive COVID-19 Disparities. Am J Epidemiol. 2020;189(11):1244-1253

43. Singer M, Herring DA, Littleton J, Rock M. Syndemics in Global Health. In: A Companion to Medical Anthropology.2011:159-179.

44. Singer M, Bulled N, Ostrach B, Mendenhall E. Syndemics and the biosocial conception of health. Lancet. 2017;389(10072):941-950

45. Gravlee CC. Systemic racism, chronic health inequities, and COVID-19: A syndemic in the making? Am J Hum Biol. 2020;32(5):e23482

46. Islam N, Lacey B, Shabnam S, et al. Social inequality and the syndemic of chronic disease and COVID-19: county-level analysis in the USA. J Epidemiol Community Health. 2021

47. Hosaka KRJ, Castanera MP, Yamada S. Structural Racism and Micronesians in Hawaii: The COVID-19 Syndemic. Asia Pac J Public Health. 2021:10105395211012188

48. Pathak EB, Menard JM, Garcia RB, Salemi JL. Social Class, Race/Ethnicity, and COVID-19 Mortality Among Working Age Adults in the United States. MedRxiv. 2021;2021.11.23.21266759

49. American Time Use Survey -- May to December 2019 and 2020 Results [press release]. July 22, 20212021 https://www.bls.gov/news.release/atus.nr0.htm.

50. Marmot M, Allen J, Goldblatt P, Herd E, Morrison J. Build Back Fairer: The COVID-19 Marmot Review. The Pandemic, Socioeconomic and Health Inequalities in England. . London: Institute of Health Equity;2020

https://www.health.org.uk/sites/default/files/upload/publications/2020/Build-back-fairer-theCOVID-19-Marmot-review.pdf.

51. Marmot M, Allen J, Goldblatt P, Herd E, Morrison J. Build Back Fairer: The COVID-19 Marmot Review. The Pandemic, Socioeconomic and Health Inequalities in England. London: University College London Institute of Health Equity 2020

https://www.instituteofhealthequity.org/resources-reports/build-back-fairer-the-covid-19marmot-review.

52. Bui DP, McCaffrey K, Friedrichs M, et al. Racial and Ethnic Disparities Among COVID-19 Cases in Workplace Outbreaks by Industry Sector - Utah, March 6-June 5, 2020. MMWR Morb Mortal Wkly Rep. 2020;69(33):1133-1138

53. Porter KA, Ramaswamy M, Koloski T, Castrodale L, McLaughlin J. COVID-19 Among Workers in the Seafood Processing Industry: Implications for Prevention Measures - Alaska, March-October 2020. MMWR Morb Mortal Wkly Rep. 2021;70(17):622-626

54. Pasco RF, Fox SJ, Johnston SC, Pignone M, Meyers LA. Estimated Association of Construction Work With Risks of COVID-19 Infection and Hospitalization in Texas. JAMA Netw Open. 2020;3(10):e2026373

55. Miller JS, Holshue M, Dostal TKH, Newman LP, Lindquist S. COVID-19 Outbreak Among Farmworkers - Okanogan County, Washington, May-August 2020. MMWR Morb Mortal Wkly Rep. 2021;70(17):617-621

56. Jesse Bonwitt BRWD, MBChB2; Dustin W. Currie, PhD1,3; Beth Lipton, DVM2; Melinda Huntington-Frazier, MSN2; Sara Jaye Sanford, MPH2; Aley Joseph Pallickaparambil, MS, MPH2; Julia Hood, PhD2; Agam K. Rao, MD1; Kaitlin Kelly-Reif, PhD1; Sara E. Luckhaupt, MD1; Sargis Pogosjans, MPH2; Scott Lindquist, MD4; Jeff Duchin, MD2; Vance Kawakami, DVM2. COVID-19 Surveillance and Investigations in Workplaces - Seattle \& King County, Washington, June 15November 15, 2020. MMWR Morb Mortal Wkly Rep 2021;70:916-921. DOI:

http://dx.doi.org/10.15585/mmwr.mm7025a3external icon. 
57. Rubenstein BL, Campbell S, Meyers AR, et al. Factors That Might Affect SARS-CoV-2 Transmission Among Foreign-Born and U.S.-Born Poultry Facility Workers - Maryland, May 2020. MMWR Morb Mortal Wkly Rep. 2020;69(50):1906-1910

58. Mora AM, Lewnard JA, Kogut $K$, et al. Risk Factors Associated With SARS-CoV-2 Infection Among Farmworkers in Monterey County, California. JAMA Network Open. 2021;4(9):e2124116e2124116 https://doi.org/10.1001/jamanetworkopen.2021.24116.

59. Chen $\mathrm{Y}-\mathrm{H}$, Glymour $\mathrm{M}$, Riley $\mathrm{A}$, et al. Excess mortality associated with the COVID-19 pandemic among Californians 18-65 years of age, by occupational sector and occupation: March through October 2020. medRxiv. 2021:2021.2001.2021.21250266 https://www.medrxiv.org/content/medrxiv/early/2021/01/22/2021.01.21.21250266.full.pdf.

60. Saitone TL, Aleks Schaefer K, Scheitrum DP. COVID-19 morbidity and mortality in U.S. meatpacking counties. Food Policy. 2021;101:102072

61. Lutrick K, Ellingson KD, Baccam Z, et al. COVID-19 Infection, Reinfection, and Vaccine Effectiveness in a Prospective Cohort of Arizona Frontline/Essential Workers: The AZ HEROES Research Protocol. JMIR Res Protoc. 2021

62. Semuels A. 'If We Don't Work, We Don't Get Paid.' How the Coronavirus Is Exposing Inequality Among America's Workers. March 4, 2020, 2020 https://time.com/5795651/coronavirusworkers-economy-inequality/

63. Hawkins D, Davis L, Kriebel D. COVID-19 deaths by occupation, Massachusetts, March 1-July 31, 2020. Am J Ind Med. 2021;64(4):238-244

64. Chen JT, Krieger N. Revealing the Unequal Burden of COVID-19 by Income, Race/Ethnicity, and Household Crowding: US County Versus Zip Code Analyses. J Public Health Manag Pract. 2021;27 Suppl 1, COVID-19 and Public Health: Looking Back, Moving Forward:S43-s56

65. Nguyen TH, Shah GH, Schwind JS, Richmond HL. Community Characteristics and COVID-19 Outcomes: A Study of 159 Counties in Georgia, United States. J Public Health Manag Pract. 2021;27(3):251-257

66. Fielding-Miller RK, Sundaram ME, Brouwer K. Social determinants of COVID-19 mortality at the county level. PLoS One. 2020;15(10):e0240151

67. Bhowmik T, Tirtha SD, Iraganaboina NC, Eluru N. A comprehensive analysis of COVID-19 transmission and mortality rates at the county level in the United States considering sociodemographics, health indicators, mobility trends and health care infrastructure attributes. PLoS One. 2021;16(4):e0249133

68. Liao TF, De Maio F. Association of Social and Economic Inequality With Coronavirus Disease 2019 Incidence and Mortality Across US Counties. JAMA Netw Open. 2021;4(1):e2034578

69. Yu Q, Salvador CE, Melani I, Berg MK, Neblett EW, Kitayama S. Racial residential segregation and economic disparity jointly exacerbate COVID-19 fatality in large American cities. Ann N Y Acad Sci. 2021

70. Paul R, Adeyemi O, Ghosh S, Pokhrel K, Arif AA. Dynamics of Covid-19 mortality and social determinants of health: a spatiotemporal analysis of exceedance probabilities. Ann Epidemiol. 2021;62:51-58

71. Dalsania AK, Fastiggi MJ, Kahlam A, et al. The Relationship Between Social Determinants of Health and Racial Disparities in COVID-19 Mortality. J Racial Ethn Health Disparities. 2021:1-8

72. Hawkins RB, Charles EJ, Mehaffey JH. Socio-economic status and COVID-19-related cases and fatalities. Public Health. 2020;189:129-134

73. Ahmad K, Erqou S, Shah N, et al. Association of poor housing conditions with COVID-19 incidence and mortality across US counties. PLoS One. 2020;15(11):e0241327 
74. Kamis C, Stolte A, West JS, et al. Overcrowding and COVID-19 mortality across U.S. counties: Are disparities growing over time? SSM Popul Health. 2021;15:100845

75. Qeadan F, Mensah NA, Tingey B, et al. The association between opioids, environmental, demographic, and socioeconomic indicators and COVID-19 mortality rates in the United States: an ecological study at the county level. Arch Public Health. 2021;79(1):101

76. Tian T, Zhang J, Hu L, et al. Risk factors associated with mortality of COVID-19 in 3125 counties of the United States. Infect Dis Poverty. 2021;10(1):3

77. Neelon B, Mutiso F, Mueller NT, Pearce JL, Benjamin-Neelon SE. Spatial and temporal trends in social vulnerability and COVID-19 incidence and death rates in the United States. PLoS One. 2021;16(3):e0248702

78. Freese KE, Vega A, Lawrence JJ, Documet PI. Social Vulnerability Is Associated with Risk of COVID-19 Related Mortality in U.S. Counties with Confirmed Cases. J Health Care Poor Underserved. 2021;32(1):245-257

79. Islam SJ, Nayak A, Hu Y, et al. Temporal trends in the association of social vulnerability and race/ethnicity with county-level COVID-19 incidence and outcomes in the USA: an ecological analysis. BMJ Open. 2021;11(7):e048086

80. Karmakar M, Lantz PM, Tipirneni R. Association of Social and Demographic Factors With COVID19 Incidence and Death Rates in the US. JAMA Netw Open. 2021;4(1):e2036462

81. Cheng KJG, Sun Y, Monnat SM. COVID-19 Death Rates Are Higher in Rural Counties With Larger Shares of Blacks and Hispanics. J Rural Health. 2020;36(4):602-608

82. Gaglioti AH, Li C, Douglas MD, et al. Population-Level Disparities in COVID-19: Measuring the Independent Association of the Proportion of Black Population on COVID-19 Cases and Deaths in US Counties. J Public Health Manag Pract. 2021;27(3):268-277

83. Correa-Agudelo E, Mersha TB, Branscum AJ, MacKinnon NJ, Cuadros DF. Identification of Vulnerable Populations and Areas at Higher Risk of COVID-19-Related Mortality during the Early Stage of the Epidemic in the United States. Int J Environ Res Public Health. 2021;18(8)

84. DuPre NC, Karimi S, Zhang $\mathrm{CH}$, et al. County-level demographic, social, economic, and lifestyle correlates of COVID-19 infection and death trajectories during the first wave of the pandemic in the United States. Sci Total Environ. 2021;786:147495

85. Khanijahani A, Tomassoni L. Socioeconomic and Racial Segregation and COVID-19: Concentrated Disadvantage and Black Concentration in Association with COVID-19 Deaths in the USA. J Racial Ethn Health Disparities. 2021:1-9

86. Torrats-Espinosa G. Using machine learning to estimate the effect of racial segregation on COVID-19 mortality in the United States. Proc Natl Acad Sci U S A. 2021;118(7)

87. Pierce JB, Harrington $\mathrm{K}, \mathrm{McC}$ abe $\mathrm{ME}$, et al. Racial/ethnic minority and neighborhood disadvantage leads to disproportionate mortality burden and years of potential life lost due to COVID-19 in Chicago, Illinois. Health Place. 2021;68:102540

88. Krieger N, Waterman PD, Chen JT. COVID-19 and Overall Mortality Inequities in the Surge in Death Rates by Zip Code Characteristics: Massachusetts, January 1 to May 19, 2020. American Journal of Public Health. 2020;110(12):1850-1852 https://ajph.aphapublications.org/doi/abs/10.2105/AJPH.2020.305913.

89. Williams DR, Lavizzo-Mourey R, Warren RC. The concept of race and health status in America. Public Health Rep. 1994;109(1):26-41

90. Smedley A, Smedley BD. Race as biology is fiction, racism as a social problem is real: Anthropological and historical perspectives on the social construction of race. Am Psychol. 2005;60(1):16-26 
91. LaVeist TA. On the study of race, racism, and health: a shift from description to explanation. Int J Health Serv. 2000;30(1):217-219

92. Chowkwanyun M, Reed AL. Racial Health Disparities and Covid-19 - Caution and Context. New England Journal of Medicine. 2020;383(3):201-203

https://www.nejm.org/doi/full/10.1056/NEJMp2012910.

93. Krieger N. Workers are people too: societal aspects of occupational health disparities--an ecosocial perspective. Am J Ind Med. 2010;53(2):104-115

94. Kuzawa CW, Sweet E. Epigenetics and the embodiment of race: developmental origins of US racial disparities in cardiovascular health. Am J Hum Biol. 2009;21(1):2-15

https://onlinelibrary.wiley.com/doi/10.1002/ajhb.20822.

95. Conching AKS, Thayer Z. Biological pathways for historical trauma to affect health: A conceptual model focusing on epigenetic modifications. Social Science \& Medicine. 2019;230:74-82 https://www.sciencedirect.com/science/article/pii/S0277953619301959.

96. Kelly MP. The relation between the social and the biological and COVID-19. Public Health. 2021;196:18-23 https://www.sciencedirect.com/science/article/pii/S0033350621001839 https://www.ncbi.nlm.nih.gov/pmc/articles/PMC8114767/pdf/main.pdf.

97. Michelen M, Manoharan L, Elkheir N, et al. Characterising long COVID: a living systematic review. BMJ Glob Health. 2021;6(9)

98. Sudre $\mathrm{CH}$, Murray $\mathrm{B}$, Varsavsky $\mathrm{T}$, et al. Attributes and predictors of long COVID. Nature Medicine. 2021;27(4):626-631 https://doi.org/10.1038/s41591-021-01292-y.

99. Cooper SM, Thomas A, Bamishigbin O. Black American Fathers Employed in Higher-Risk Contexts for Contracting COVID-19: Implications for Individual Wellbeing and Work-Family Spillover. Am J Mens Health. 2021;15(2):15579883211005617

100. Occupational Safety and Health Act In: Congress sUS, ed. Vol 29 U.S.C. ch. $15 \S 651$ et seq.1970 https://www.osha.gov/laws-regs/oshact/section_5.

101. Michaels D, Wagner GR. Halting Workplace COVID-19 Transmission: An Urgent Proposal to Protect American Workers. New York: The Century Foundation; October 15, 20202020 https://tcf.org/content/report/halting-workplace-covid-19-transmission-urgent-proposalprotect-american-workers/.

102. AFL-CIO. Death on the Job: The Toll of Neglect. A National and State-by-State Profile of Worker Safety and Health in the United States. Washington DC May 20212021 https://aflcio.org/reports/death-job-toll-neglect-2020.

103. Dennerlein JT, Burke L, Sabbath EL, et al. An Integrative Total Worker Health Framework for Keeping Workers Safe and Healthy During the COVID-19 Pandemic. Hum Factors. 2020;62(5):689-696

104. OSHA releases emergency temporary standard on COVID-19 for health care workers. Safety and Health Magazine. https://www.safetyandhealthmagazine.com/articles/21336-osha-releasesemergency-temporary-standard-on-covid-19-for-health-care-workers.

105. Krieger N. Structural Racism, Health Inequities, and the Two-Edged Sword of Data: Structural Problems Require Structural Solutions. Front Public Health. 2021;9(655447)

106. Services CfMaM. COVID-19 Nursing Home Data. In: Services CfMaM, ed2021 https://data.cms.gov/covid-19/covid-19-nursing-home-data.

107. Douglas L. Mapping Covid-19 outbreaks in the food system. 2021.

108. Douglas L. FERN's Covid-19 Mapping Project concludes. In: Food and Environment Reporting Network; 2021 https://thefern.org/blog_posts/ferns-covid-19-mapping-project-concludes/. 
109. McNicholas C, Rhinehart L, Poydock M, Shierholz H, Perez D. Why unions are good for workersespecially in a crisis like COVID-19. Washington DC: Economic Policy Institute;2020 https://files.epi.org/pdf/204014.pdf.

110. Crowell NA, Hanson A, Boudreau L, Robbins R, Sokas RK. Union Efforts to Reduce COVID-19 Infections Among Grocery Store Workers. New Solut. 2021;31(2):170-177

111. Dean A, McCallum J, Kimmel S, Venkataramani A. lowa School Districts Were More Likely To Adopt COVID-19 Mask Mandates Where Teachers Were Unionized. Health Aff (Millwood). 2021;40(8):1270-1276

112. Dean A, Venkataramani A, Kimmel S. Mortality Rates From COVID-19 Are Lower In Unionized Nursing Homes. Health Aff (Millwood). 2020;39(11):1993-2001

113. Owen MJ, Sundberg MA, Dionne J, Kosobuski AW. The Impact of COVID-19 on American Indian and Alaska Native Communities: A Call for Better Relational Models. Am J Public Health. 2021;111(5):801-803

114. Rosenthal EL, Menking P, Begay MG. Fighting the COVID-19 Merciless Monster: Lives on the Line-Community Health Representatives' Roles in the Pandemic Battle on the Navajo Nation. $J$ Ambul Care Manage. 2020;43(4):301-305

115. Kaholokula JK, Samoa RA, Miyamoto RES, Palafox N, Daniels SA. COVID-19 Special Column: COVID-19 Hits Native Hawaiian and Pacific Islander Communities the Hardest. Hawaii J Health Soc Welf. 2020;79(5):144-146

116. Liebman AK, Seda CH, Galván AR. Farmworkers and COVID-19: Community-Based Partnerships to Address Health and Safety. Am J Public Health. 2021;111(8):1456-1458

117. Oliver MN, Muntaner C. Researching Health Inequities Among African Americans: The Imperative to Understand Social Class. International Journal of Health Services. 2005;35(3):485498

118. Landrigan PJ, Ferrer L, Keenan J. COVID-19 and Health Disparities: Structural Evil Unmasked. Ann Glob Health. 2021;87(1):34

119. Sember R, Fullilove MT, Fullilove RE. What We "Cannot Not Know in America": 400 Years of Inequality and Seven Sins. Frontiers in Public Health. 2021;9(777) https://www.frontiersin.org/article/10.3389/fpubh.2021.678053. 